\title{
Effect of Polymer Phase Transition Behavior on Temperature-Responsive Polymer-Modified Liposomes for siRNA Transfection
}

\author{
Kenichi Nagase *(D), Momoko Hasegawa, Eri Ayano, Yoshie Maitani and Hideko Kanazawa *(D) \\ Faculty of Pharmacy, Keio University, 1-5-30 Shibakoen, Minato, Tokyo 105-8512, Japan; \\ peach-hasegawa.3720048@z6.keio.jp (M.H.); ayano-er@pha.keio.ac.jp (E.A.); maitani-y@u01.gate01.com (Y.M.) \\ * Correspondence: nagase-kn@pha.keio.ac.jp (K.N.); kanazawa-hd@pha.keio.ac.jp (H.K.); \\ Tel.: +81-3-5400-1378 (K.N.)
}

Received: 10 January 2019; Accepted: 15 January 2019; Published: 19 January 2019

\begin{abstract}
Small interfering RNAs (siRNAs) have been attracting significant attention owing to their gene silencing properties, which can be utilized to treat intractable diseases. In this study, two temperature-responsive liposomal siRNA carriers were prepared by modifying liposomes with different polymers-poly( $N$-isopropylacrylamide-co- $N, N$-dimethylaminopropyl acrylamide) (P(NIPAAm-co-DMAPAAm)) and poly(N-isopropylacrylamide-co- $N, N$-dimethylacrylamide) P(NIPAAm-co-DMAAm). The phase transition of P(NIPAAm-co-DMAPAAm) was sharper than that of P(NIPAAm-co-DMAAm), which is attributed to the lower co-monomer content. The temperature dependent fixed aqueous layer thickness (FALT) of the prepared liposomes indicated that modifying liposomes with P(NIPAAm-co-DMAPAAm) led to a significant change in the thickness of the fixed aqueous monolayer between $37{ }^{\circ} \mathrm{C}$ and $42{ }^{\circ} \mathrm{C}$; while P(NIPAAm-co-DMAAm) modification led to FALT changes over a broader temperature range. The temperature-responsive liposomes exhibited cellular uptake at $42{ }^{\circ} \mathrm{C}$, but were not taken up by cells at $37^{\circ} \mathrm{C}$. This is likely because the thermoresponsive hydrophilic/hydrophobic changes at the liposome surface induced temperature-responsive cellular uptake. Additionally, siRNA transfection of cells for the prevention of luciferase and vascular endothelial growth factor (VEGF) expression was modulated by external temperature changes. P(NIPAAm-co-DMAPAAm) modified liposomes in particular exhibited effective siRNA transfection properties with low cytotoxicity compared with P(NIPAAm-co-DMAAm) modified analogues. These results indicated that the prepared temperature-responsive liposomes could be used as effective siRNA carriers whose transfection properties can be modulated by temperature.
\end{abstract}

Keywords: thermoresponsive polymer; siRNA delivery; liposome; transfection

\section{Introduction}

Nucleic acid therapeutics have been investigated as potential treatments for intractable diseases [1]. One promising group of nucleic acid therapeutics is small interfering RNAs (siRNAs) because they induce messenger RNA (mRNA) degradation in cells and RNA interference, leading to the suppression of gene expression [1-4]. Various diseases caused by the expression of pathogenic protein can therefore be treated with siRNA.

However, it is challenging to effectively deliver siRNA to cells because of the electrostatic repulsion between the siRNA and the cell membrane, and the instability of siRNA. To overcome these challenges, siRNA carriers have been investigated to facilitate delivery into cells. Cationic liposomes are widely used as nucleic acid carriers since the cationic charge of the liposomes leads to the formation of a 
complex with the anionic nucleic acid fragments—called a lipoplex—which enhances cellular uptake. However, cationic liposomes are unstable in vivo because they tend to aggregate with serum proteins. Therefore, polymer coated liposomes have been investigated. Polyethylene glycol (PEG) modification of liposomes leads to excellent stability in the blood stream [5-7]. However, PEG modified liposomes exhibit low cell interaction as a result of their hydrophilic properties, resulting in lower delivery efficiency. Therefore, temperature-responsive polymer-modified liposomes have been investigated to achieve temperature modulated cellular uptake [8-11]. Poly( $N$-isopropylacrylamide) (PNIPAAm) is often used as a temperature responsive polymer for liposome modification.

PNIPAAm is widely used as a thermoresponsive polymer in biomedical applications such as drug delivery [12-14], bioseparation [15-19], biosensing, bioimaging and diagnostic devices [20-22], and cell culture substrates for tissue engineering and regenerative medicines [23-30]. PNIPAAm exhibits temperature-responsive hydrophilic and hydrophobic changes across its lower critical solution temperature (LCST) of $32{ }^{\circ} \mathrm{C}$, which can be attributed to hydration and dehydration of the polymer chain [31-33], and thermoresponsive polymer-modified liposomes have been developed based on this property. Below the LCST, PNIPAAm modified liposomes are hydrophilic, which prevents cell uptake. In contrast, above the LCST, temperature-modulated liposomes become hydrophobic, leading to enhanced cellular uptake. However, the intrinsic LCST of PNIPAAm is $32{ }^{\circ} \mathrm{C}$, which is not appropriate for use at physiological temperature $\left(37^{\circ} \mathrm{C}\right)$. To tune the LCST of the polymer to $\sim 37^{\circ} \mathrm{C}$, copolymerization of hydrophilic monomer into the PNIPAAm chain has been reported [34-36]. N,N-Dimethylacrylamide (DMAAm) and $\mathrm{N}, \mathrm{N}$-dimethylaminopropyl acrylamide (DMAPAAm) have frequently been used as co-monomers for modulation of the LCST of PNIPAAm to body temperature [37-41]. Both DMAAm and DMAPAAm are acrylamide monomers with relatively hydrophilic properties compared with PNIPAAm, and their introduction into the polymer chain results in the elevation of the LCST. DMAPAAm has cationic properties and is therefore strongly hydrophilic. Therefore, a relatively low degree of copolymerization of DMAPAAm into PNIPAAm is sufficient for LCST modulation $[40,41]$. In contrast, DMAAm is neutral compared with DMAPAAm and exhibits relatively weak hydrophilic properties. Therefore, a larger amount of DMAAm is required in the copolymerization for modulation of the LCST [37-39]. If these polymers were used for liposome modification to produce siRNA carriers, the difference in the polymer properties would affect the temperature responsive behavior of the modified liposome carriers, leading to efficient siRNA transfection.

In this study, two types of thermoresponsive polymer-modified liposome were prepared using P(NIPAAm-co-DMAPAAm) and P(NIPAAm-co-DMAAm) (Figure 1). Characterization of the liposomes was carried out, including evaluation of the temperature-responsive property changes. Additionally, temperature-modulated siRNA transfection for suppression of luciferase and VEGF expressions in cells was performed. The polymer most appropriate for liposome modification was determined from the findings. 
(A)
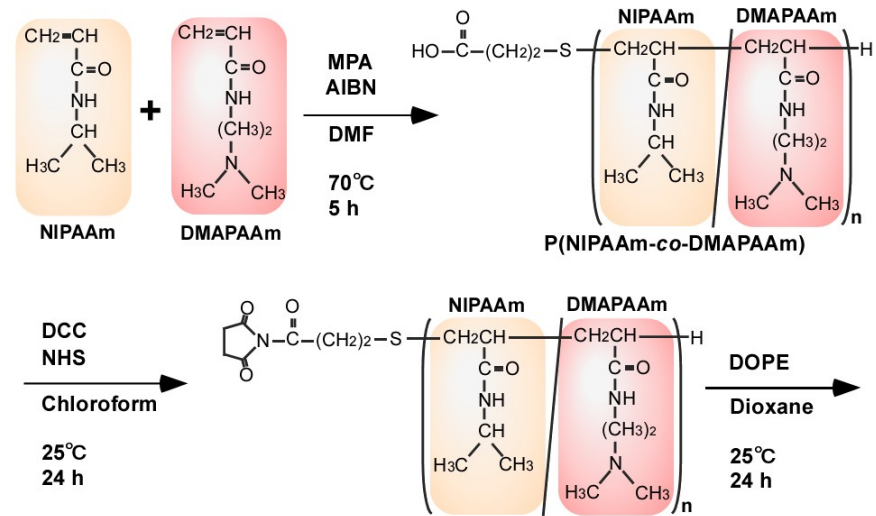

P(NIPAAm-co-DMAPAAm) with active ester

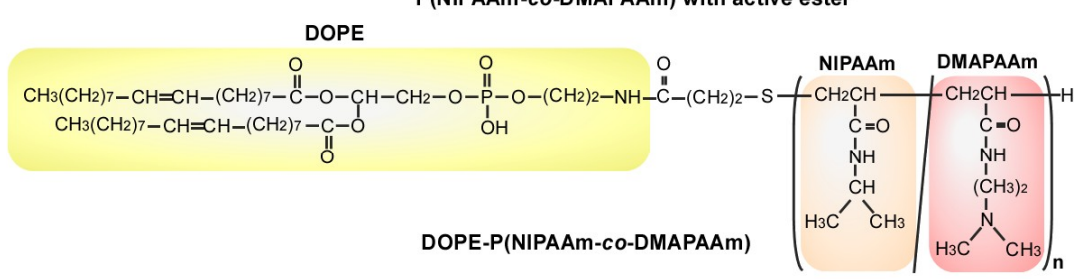

(B)
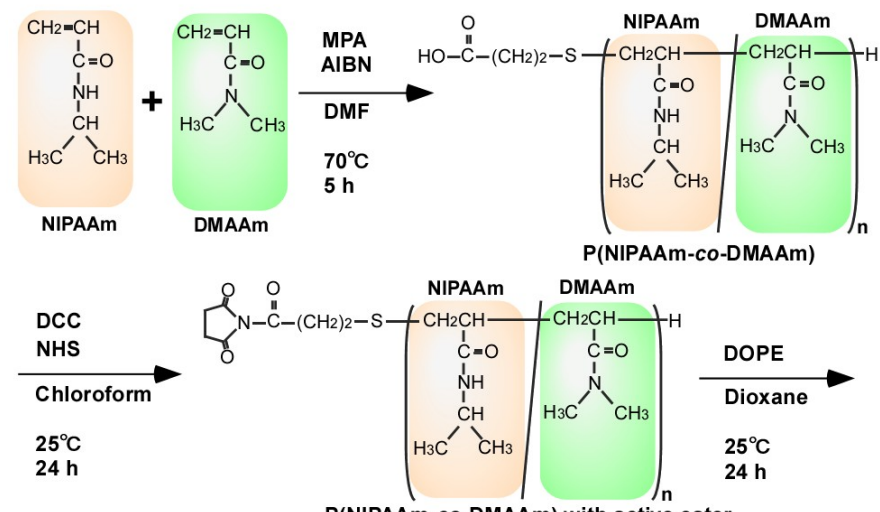

P(NIPAAm-co-DMAAm) with active ester DOPE

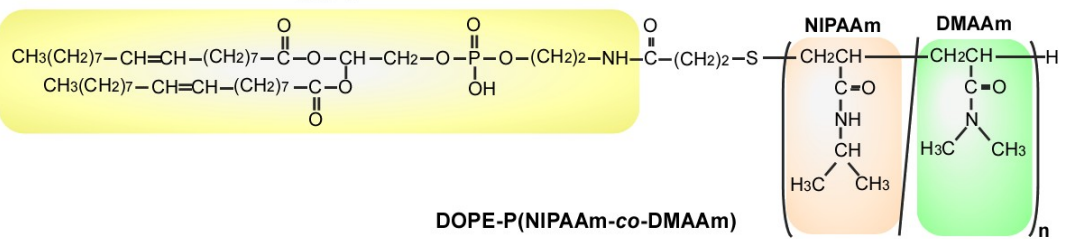

(C)

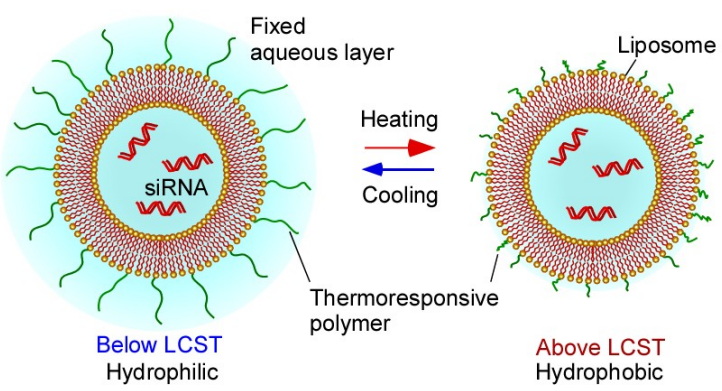

Figure 1. Schemes for the preparation of (A) P(NIPAAm-co-DMAPAAm) modified DOPE and (B) P(NIPAAm-co-DMAAm) modified DOPE. (C) Illustration of a thermoresponsive polymer-modified liposome as an siRNA carrier. 


\section{Results and Discussion}

\subsection{Characterization of the Prepared Polymers}

The properties of the synthesized polymers were investigated using gel permeation chromatography (GPC), ${ }^{1} \mathrm{H}$ NMR, and titration (Table 1). The phase transition profiles of the prepared polymers were also measured (Figure 2). GPC showed that the molecular weights of P(NIPAAm-co-DMAPAAm) and P(NIPAAm-co-DMAAm) were 17,000 and 15,000 g/mol, respectively. The molecular weight of the polymers determined by GPC was higher than expected as the polymerization procedure was designed to give polymers with a molecular weight of $10,000 \mathrm{~g} / \mathrm{mol}$. It is possible that the determined molecular weights were inaccurate because the calibration of the GPC columns was performed using polyethylene glycol standards, therefore, the molecular weights were also determined by ${ }^{1} \mathrm{H}$ NMR and acid-base titration. We experimentally assessed whether polymer molecular weight determination using ${ }^{1} \mathrm{H}$ NMR or acid-base titration is more accurate than using GPC in this case. The molecular weight of P(NIPAAm-co-DMAAm) was determined by acid-base titration because titration is known to be a relatively accurate method for measuring molecular weight compared with using ${ }^{1} \mathrm{H}$ NMR or GPC. However, it is difficult to determine the molecular weight of P(NIPAAm-co-DMAPAAm) by acid-base titration because P(NIPAAm-co-DMAPAAm) is a weak base. We therefore measured the molecular weight of P(NIPAAm-co-DMAPAAm) by ${ }^{1} \mathrm{H}$ NMR, despite molecular weight observation using ${ }^{1} \mathrm{H}$ NMR being less accurate than titration.

As a result, it was concluded that the molecular weights of P(NIPAAm-co-DMAPAAm) and P(NIPAAm-co-DMAAm) were 11,000 and 13,500, respectively. We consider these values to be more accurate than those determined by GPC.

The phase transition behavior of the prepared polymers was established from the temperature-dependent transmittance change of the solution. The LCSTs of P(NIPAAm-coDMAPAAm) and P(NIPAAm-co-DMAAm) were observed at $41.7^{\circ} \mathrm{C}$ and $41.9^{\circ} \mathrm{C}$, respectively, which are appropriate temperatures for temperature-modulated cellular uptake of liposomes. In addition, P(NIPAAm-co-DMAPAAm) exhibited a sharp phase transition profile, while the phase transition of $\mathrm{P}(\mathrm{NIPAAm}-\mathrm{co}$-DMAAm) proceeded over a broad temperature range. This difference is attributed to the copolymer content. P(NIPAAm-co-DMAPAAm) consisted of $94 \mathrm{~mol} \%$ NIPAAm and $6 \mathrm{~mol} \%$ DMAPAAm, while P(NIPAAm-co-DMAAm) consisted of 69.5 mol \% NIPAAm and $30.5 \mathrm{~mol} \%$ DMAAm. Previous reports have indicated that the phase transition of PNIPAAm copolymer developed a broad profile as co-monomer content increased [42,43]. Therefore, P(NIPAAm-co-DMAPAAm) with low co-monomer content, exhibited a sharp transition profile.

Table 1. Characterization of thermoresponsive polymers.

\begin{tabular}{|c|c|c|c|c|c|}
\hline \multirow{3}{*}{ Polymer } & \multicolumn{4}{|c|}{ Molecular Weight } & \multirow{3}{*}{$\operatorname{LCST}\left({ }^{\circ} \mathrm{C}\right)^{\mathrm{d}}$} \\
\hline & \multicolumn{2}{|c|}{ GPC } & \multirow{2}{*}{${ }^{1} \mathbf{H}_{\mathrm{NMR}}{ }^{\mathrm{b}}$} & \multirow{2}{*}{ Titration ${ }^{c}$} & \\
\hline & $\mathrm{Mn}^{\mathrm{a}}$ & $\mathbf{M w}^{\mathrm{a}}$ & & & \\
\hline P(NIPAAm-co-DMAPAAm) & 17,000 & 4.4 & 11,000 & & 41.9 \\
\hline P(NIPAAm-co-DMAAm) & 15,000 & 3.5 & & 13,500 & 41.7 \\
\hline
\end{tabular}




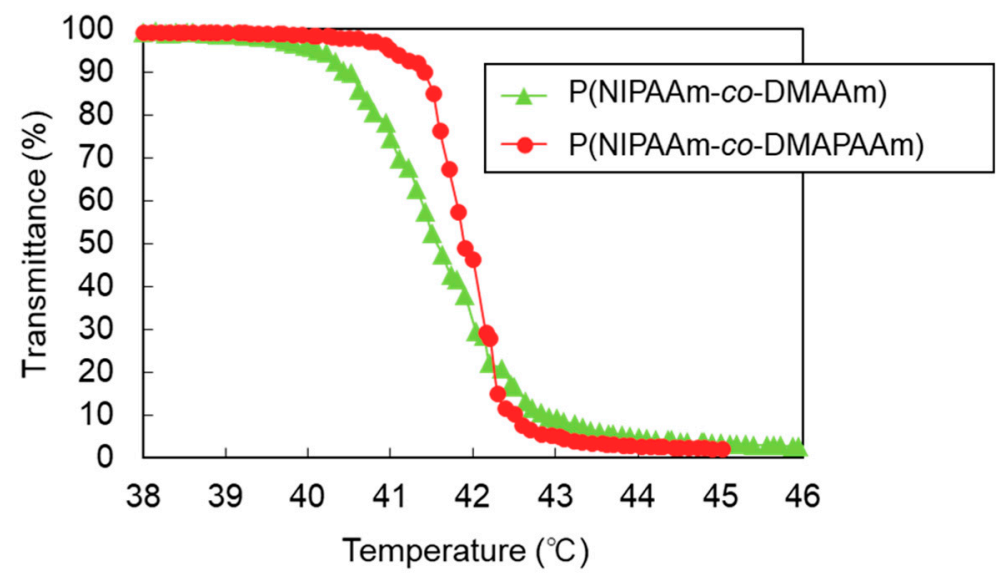

Figure 2. Phase transition behavior of the thermoresponsive polymers in phosphate buffer saline (PBS). The lower critical solution temperature (LCST) was defined as the temperature at which the optical transmittance of the polymer solution was $50 \%$ of the difference between the maximum and minimum transmittances.

\subsection{Characterization of the Prepared Liposomes}

The prepared liposomes were characterized by measuring their size, polydispersity index (PDI), and zeta potential (Table 2). The size of the non-modified liposomes was $135.8 \mathrm{~nm}$. The polymer-modified liposomes exhibited a slightly larger size than the unmodified liposomes, indicating that the modified polymer extended to the outer surface of the liposomes. All liposomes exhibited small PDI values indicating that the procedure used in this study resulted in uniformly sized liposomes. Zeta potential measurement of the non-modified liposomes showed a large value, which is attributed to the cationic properties of 1,2-dioleoyl-3-trimethylammonium propane (chloride salt) (DOTAP). The polymer-modified liposomes exhibited lower zeta potential values than the unmodified liposomes. This is because the presence of the polymer on the liposome shields the cationic properties of DOTAP. Additionally, after the liposome-siRNA complex formation, the zeta potential value decreased. This is because the cationic properties of DOTAP were reduced by complex formation with siRNA.

Table 2. Characterization of the prepared liposomes.

\begin{tabular}{|c|c|c|c|c|}
\hline Modified Polymer & Sample ${ }^{a}$ & $\operatorname{Diameter}^{\mathrm{b}}(\mathrm{nm})$ & PDI $^{b}$ & Zeta Potential ${ }^{\mathrm{d}}(\mathrm{mV})$ \\
\hline \multirow{4}{*}{ P(NIPAAm-co-DMAPAAm) } & $\operatorname{siRNA}(-)$ & $166.6 \pm 1.5$ & 0.14 & $43.05 \pm 1.08$ \\
\hline & charge ratio $(+/-)=5$ & $168.3 \pm 1.0$ & 0.08 & $20.95 \pm 0.13$ \\
\hline & charge ratio $(+/-)=10$ & $171.4 \pm 7.9$ & 0.07 & $27.78 \pm 1.64$ \\
\hline & charge ratio $(+/-)=20$ & $169.1 \pm 7.3$ & 0.09 & $35.24 \pm 0.36$ \\
\hline \multirow{4}{*}{ P(NIPAAm-co-DMAAm) } & $\operatorname{siRNA}(-)$ & $164.2 \pm 7.3$ & 0.19 & $52.32 \pm 1.39$ \\
\hline & charge ratio $(+/-)=5$ & $170.5 \pm 2.4$ & 0.12 & $23.28 \pm 0.69$ \\
\hline & charge ratio $(+/-)=10$ & $158.1 \pm 6.9$ & 0.12 & $35.22 \pm 0.72$ \\
\hline & charge ratio $(+/-)=20$ & $150.3 \pm 0.4$ & 0.13 & $38.79 \pm 0.88$ \\
\hline \multirow{4}{*}{ Non-modified } & $\operatorname{siRNA}(-)$ & $135.8 \pm 0.7$ & 0.24 & $62.06 \pm 0.35$ \\
\hline & charge ratio $(+/-)=5$ & & & $29.16 \pm 5.20$ \\
\hline & charge ratio $(+/-)=10$ & N.D. ${ }^{c}$ & N.D. ${ }^{c}$ & $47.45 \pm 0.57$ \\
\hline & charge ratio $(+/-)=20$ & & & $50.67 \pm 1.03$ \\
\hline
\end{tabular}

${ }^{a}$ Charge ratio (+/-) was obtained from the molar ratio of DOTAP to siRNA phosphate. ${ }^{b}$ Determined by measuring dynamic light scattering. ${ }^{c}$ N.D. indicates not detected owing to precipitation. ${ }^{\mathrm{d}}$ Determined using a zeta potential analyzer.

The stability of the liposomes was investigated by measuring the time course of the absorbance of the liposome suspension with human serum (Figure 3). When the liposomes were suspended in serum solution, the suspension exhibited absorbance. In contrast, when liposomes formed aggregates with serum proteins, they tended to settle out of suspension leaving a clear supernatant and reducing the 
absorbance. The absorbance of the non-modified liposome suspension decreased promptly, indicating that non-modified liposomes tend to aggregate with human serum. In contrast, for liposomes modified with PEG, P(NIPAAm-co-DMAPAAm), and P(NIPAAm-co-DMAAm), the absorbance of the suspension was maintained. This result indicates that polymer-modified liposomes have high stability even in the presence of serum.

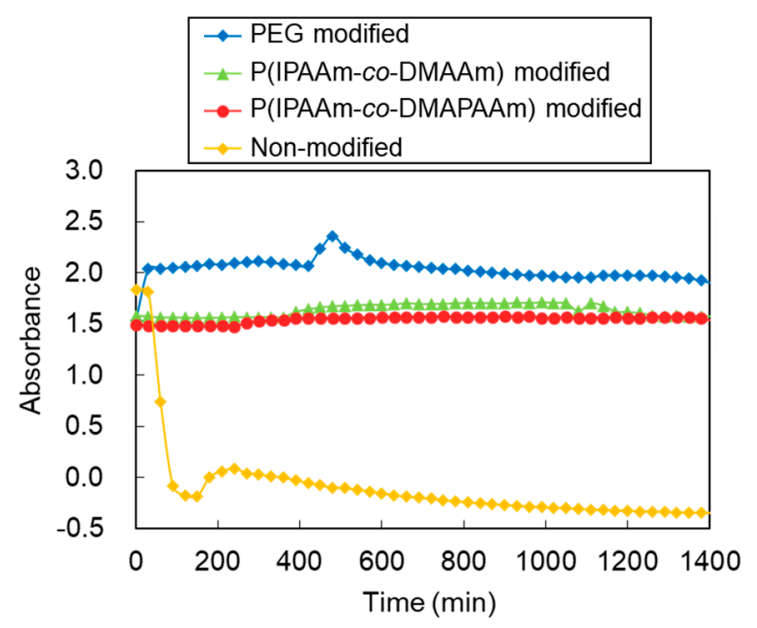

Figure 3. Stability of liposomes in serum for $24 \mathrm{~h}$ at $37^{\circ} \mathrm{C}$. Monitoring wavelength: $450 \mathrm{~nm}$. Serum concentration: $50 v / v \%$.

The temperature-dependent size change of the liposomes was observed using PBS as the suspension solvent (Figure 4). PEG modified liposomes maintained their size as the temperature was increased. In contrast, P(NIPAAm-co-DMAPAAm) and P(NIPAAm-co-DMAAm) modified liposomes exhibited an increase in size above the LCST of the polymers. At lower temperature, $\mathrm{P}(\mathrm{NIPAAm}-\mathrm{co}$-DMAPAAm) and P(NIPAAm-co-DMAAm) were hydrated and extended, leading to the formation of an aqueous outer liposome layer, which prevented the aggregation of the liposomes. Above the LCST, the polymers became hydrophobic, which is attributed to dehydration, leading to a reduction in the aqueous layer of the liposomes. The reduced aqueous layer induced aggregation of the liposomes, leading to an increase of the observed liposome size. In addition, above the LCST of the polymers, P(NIPAAm-co-DMAPAAm) modified liposomes exhibited a clear increase in size compared with P(NIPAAm-co-DMAAm) modified liposomes. One possible reason for this observation is the difference in the conformations of P(NIPAAm-co-DMAPAAm) and P(NIPAAm-co-DMAAm) following shrinkage. Above the LCST, both polymers change their conformation to the shrunken state. $\mathrm{P}$ (NIPAAm-co-DMAPAAm) has a slight positive charge in the polymer chain, leading to suppression of shrinkage. Therefore, the strong positive charge of the liposome was shielded by the polymer above the LCST, leading to aggregation of the liposomes. In contrast, P(NIPAAm-co-DMAAm) has no positive charge and tends to be compact and shrunken above LCST. Therefore, the strong positive charge of the liposome was exposed, leading to suppression of the aggregation of the liposomes owing to electrostatic repulsion.

To investigate the aqueous layer of the thermoresponsive polymer-modified liposomes, the fixed aqueous layer thickness was measured at various temperatures using a previously reported procedure [10] (Figure 5). Both of the thermoresponsive polymer-modified liposomes exhibited reduced aqueous layer thickness with increasing temperature. P(NIPAAm-co-DMAPAAm) modified liposomes in particular exhibited notable aqueous layer reduction across the LCST, while the aqueous layer of P(NIPAAm-co-DMAAm) gradually decreased over a broad temperature range from $30^{\circ} \mathrm{C}$ to $42{ }^{\circ} \mathrm{C}$. This observation is attributed to the difference in the phase transition properties between P(NIPAAm-co-DMAPAAm) and P(NIPAAm-co-DMAAm). Since P(NIPAAm-co-DMAAm) has a large DMAAm content $(30.5 \mathrm{~mol} \%)$, a broad phase transition proceeded with increasing temperature. 
In contrast, P(NIPAAm-co-DMAPAAm) contained a low DMAPAAm composition (6 mol \%) and exhibited a sharp phase transition temperature. The fixed aqueous layer of P(NIPAAm-co-DMAPAAm) liposomes therefore exhibited a marked decrease across the LCST.

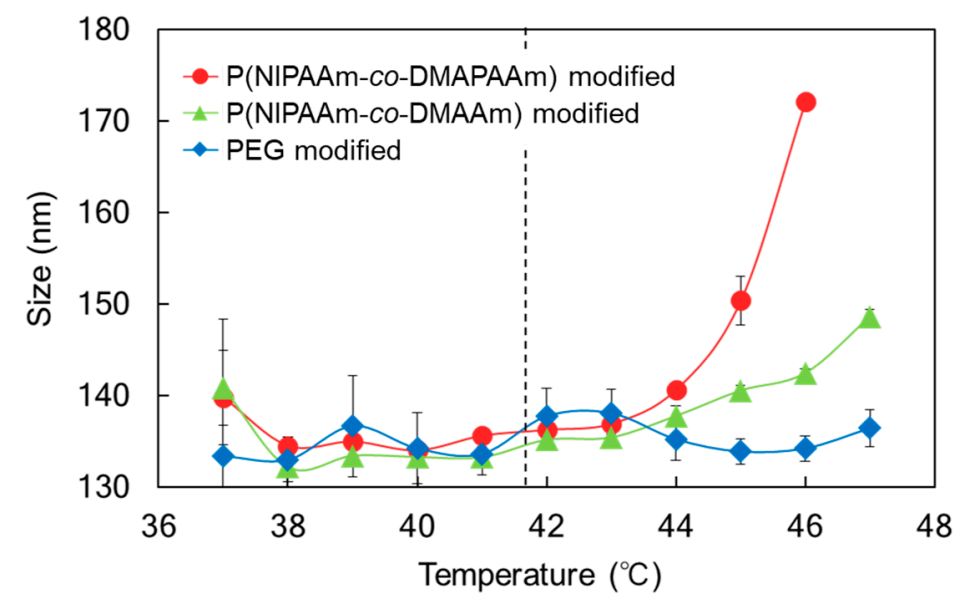

Figure 4. Temperature dependent size change of liposomes in PBS. The dashed line indicates the LCST of the thermoresponsive polymers.
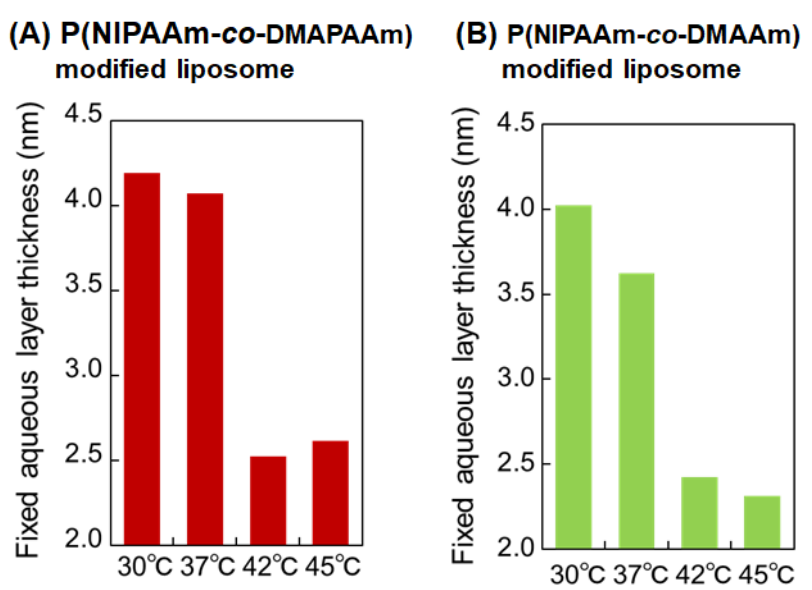

Figure 5. Temperature dependence of the fixed aqueous layer thickness (FALT) of temperatureresponsive liposomes. The FALT was calculated using Gouy-Chapman theory.

\subsection{Cellular Uptake of Liposomes}

To investigate the temperature-dependent cellular uptake properties of the liposome-siRNA complex, cellular uptake was observed at $37^{\circ} \mathrm{C}$ and $42{ }^{\circ} \mathrm{C}$ using Alexa fluor 555 labeled siRNA and fluorescence microscopy (Figure 6). Non-modified liposomes tended to aggregate, leading to an uneven distribution outside the cells. PEG modified liposomes were not taken up at $37^{\circ} \mathrm{C}$ or $42{ }^{\circ} \mathrm{C}$ because the liposomes were relatively hydrophilic. Lipofectamine RNAiMax, a commercially available transfection reagent, was effectively taken up into cells at both $37^{\circ} \mathrm{C}$ and $42^{\circ} \mathrm{C}$, and an even distribution of Alexa fluor 555 labeled siRNA was observed in cells. In the case of the temperature-responsive liposomes, cellular uptake of the liposome-siRNA complex was observed at $42{ }^{\circ} \mathrm{C}$, but was not observed at $37^{\circ} \mathrm{C}$. This observation is attributed to the temperature-responsive properties of the polymer on the liposome surface. The P(NIPAAm-co-DMAPAAm) and P(NIPAAm-co-DMAAm) on the liposome surface became hydrophobic at $42{ }^{\circ} \mathrm{C}$, leading to an enhanced hydrophobic interaction between the cells and liposomes. Therefore, the liposome-siRNA complex was taken up into cells at $42{ }^{\circ} \mathrm{C}$. In contrast, thermoresponsive polymer was hydrophilic at $37^{\circ} \mathrm{C}$, leading to prevention of temperature responsive polymer-modified liposome uptake. In addition, a previous investigation reported that the 
cellular uptake of temperature-responsive liposomes occurred via microtubule-dependent transport and clathrin-mediated endocytosis rather than caveolin-mediated endocytosis $[10,11]$. These results indicate that the prepared thermoresponsive polymer-modified liposomes can modulate siRNA transfection through simple temperature change.

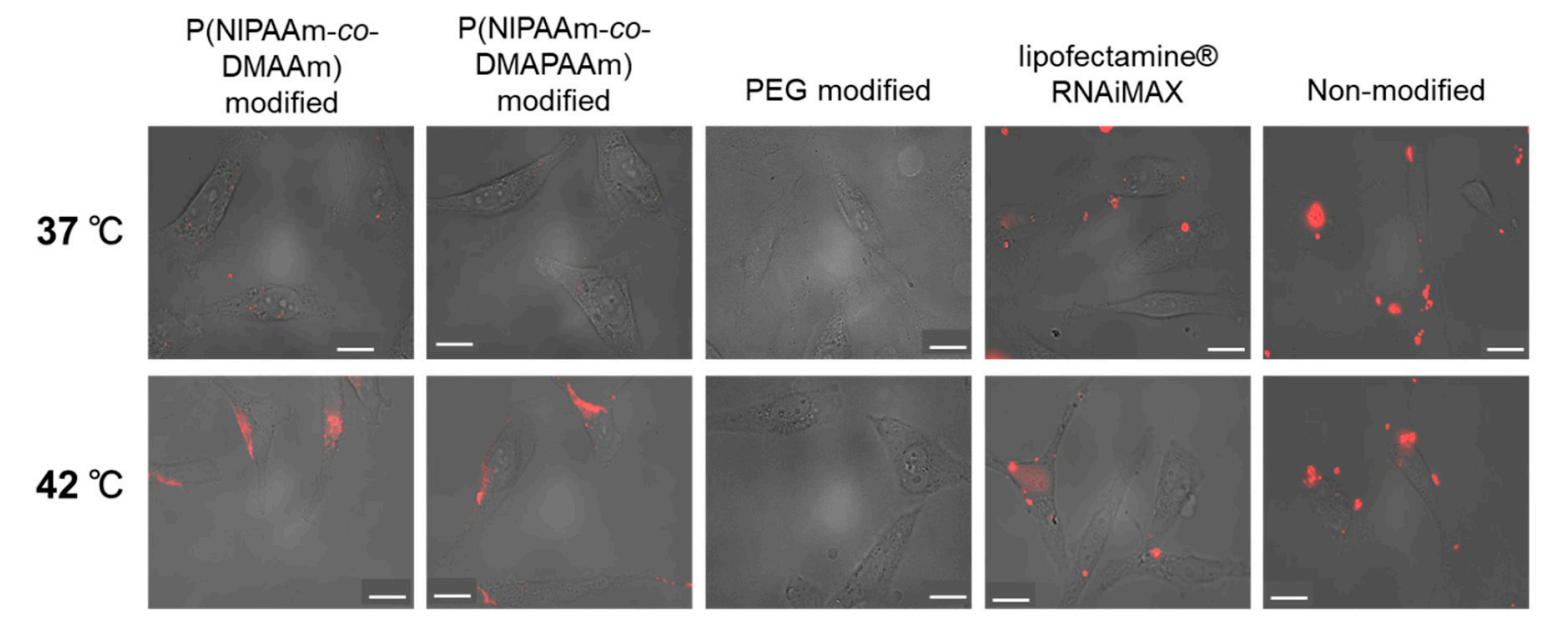

Figure 6. Cellular uptake of liposome-siRNA complex at $37^{\circ} \mathrm{C}$ and $42{ }^{\circ} \mathrm{C}$ using Alexa fluor 555 labeled siRNA and luciferase expressing HeLa cells. The liposome-siRNA complex and cells were incubated for $4 \mathrm{~h}$ at $37^{\circ} \mathrm{C}$ and $42{ }^{\circ} \mathrm{C}$. The images were prepared by merging the phase contrast cell images and fluorescent siRNA images. The scale bar indicates $20 \mu \mathrm{m}$.

\subsection{Gene Silencing Activity of the Prepared Liposomes}

In order to investigate the gene silencing activity of the prepared temperature responsive liposomes, liposome-siRNA complexes were prepared and siRNA transfection was evaluated using luciferase expressing HeLa cells. First, the optimal charge ratio $(+/-)$ of the prepared thermoresponsive liposomes was investigated (Figure 7). Luciferase activity was reduced by increasing the charge ratio $(+/-)$ because electrostatic interaction between the liposome and cell membrane increased with increasing charge ratio $(+/-)$. However, cytotoxicity is expected to increase with increasing charge ratio $(+/-)$. In addition, at high charge ratio $(+/-)$, luciferase activity was high even at $37^{\circ} \mathrm{C}$, indicating that temperature modulation was not effective. In contrast, at a charge ratio $(+/-)$ of 5:1, temperature-modulated gene silencing was observed. Relatively low gene silencing activity was observed at $37{ }^{\circ} \mathrm{C}$, and high gene silencing was observed at $42{ }^{\circ} \mathrm{C}$. The results show that a charge ratio $(+/-)$ of 5:1 provides optimal conditions for temperature-modulated transfection of siRNA.

With a charge ratio (+/-) of 5:1, temperature-dependent gene silencing activity was observed using temperature-responsive liposomes (Figure 8). Non-modified liposomes, PEG modified liposomes, commercially available transfection reagent, and siRNA alone were also measured for comparison. When only siRNA was used for transfection, luciferase activity was not reduced at either $37^{\circ} \mathrm{C}$ or $42{ }^{\circ} \mathrm{C}$, indicating that siRNA was not taken up by the cells. PEG modified liposomes did not reduce the luciferase activity at either $37^{\circ} \mathrm{C}$ or $42^{\circ} \mathrm{C}$ because the PEG modified liposomes did not tend to be taken up owing to their hydrophilic properties. Non-modified liposomes reduced the luciferase activity at both temperatures, indicating that the liposome-siRNA complex was taken up by the cells and siRNA was delivered to suppress the luciferase activity. Both temperature-responsive liposomes reduced luciferase activity at $42^{\circ} \mathrm{C}$, but it was not suppressed at $37^{\circ} \mathrm{C}$. This result indicates that temperature-responsive liposomes can modulate siRNA delivery into cells and perform gene silencing as a result of external temperature change. This is because the thermoresponsive polymer on the liposomes becomes hydrophobic above the LCST, resulting in liposome uptake and siRNA delivery into the cells. In contrast, below the LCST, the thermoresponsive polymers become hydrophilic, leading to prevention of cellular uptake. In addition, P(NIPAAm-co-DMAPAAm) modified liposomes 
exhibited more effective temperature-modulated siRNA delivery into cells compared with the P(NIPAAm-co-DMAAm) modified liposome. This is because P(NIPAAm-co-DMAPAAm) has sharp phase transition properties compared with those of P(NIPAAm-co-DMAAm), which is attributed to the lower co-monomer content of P(NIPAAm-co-DMAPAAm).

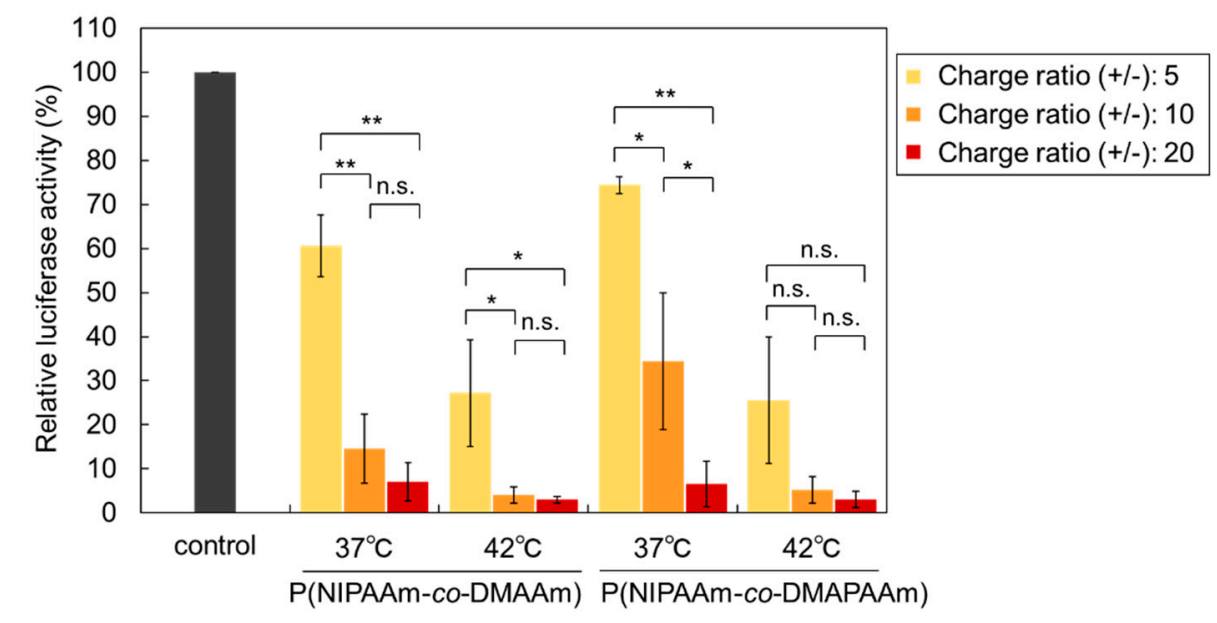

Figure 7. Effect of the charge ratio on the gene silencing activity of Luc-HeLa cells transfected with Luc-siRNA. siRNA was transfected for $4 \mathrm{~h}$ at $37^{\circ} \mathrm{C}$ or $42{ }^{\circ} \mathrm{C}$ using liposomes and lipofectamine RNAiMAX. The data are mean \pm standard deviation (SD) $\left(n=3\right.$ or $4,{ }^{* *} p<0.01,{ }^{*} p<0.05$, and n.s.: not significant).

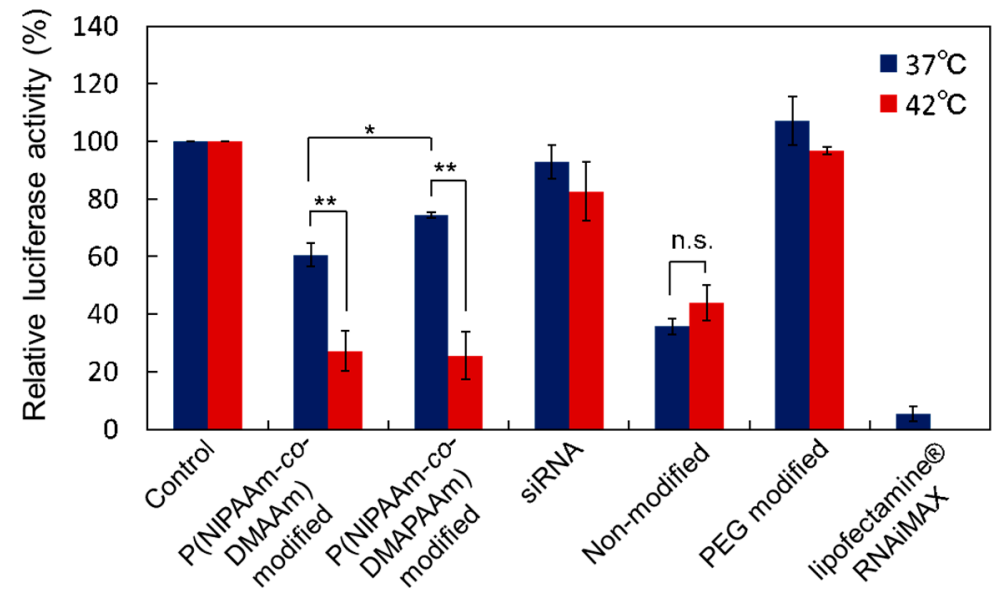

Figure 8. Effect of temperature on gene silencing activity of Luc-HeLa cells transfected with Luc-siRNA. siRNA was transfected for $4 \mathrm{~h}$ at $37{ }^{\circ} \mathrm{C}$ or $42{ }^{\circ} \mathrm{C}$ using liposomes and lipofectamine RNAiMAX. The charge ratio (+/ $)$ was 5:1 and the siRNA concentration was $25 \mathrm{nM}$. The data are mean \pm standard deviation (SD). ( $n=3$ or $4,{ }^{* *} p<0.01,{ }^{*} p<0.05$, and n.s.: not significant).

Cell viability after the siRNA transfection was evaluated by WST-8 assay (Figure 9). Non-modified liposome and Lipofectamine RNAiMax reduced the cell viability, which is likely a result of the cationic properties of the non-modified liposome and Lipofectamine RNAiMax. In contrast, thermoresponsive liposomes exhibited high cell viability compared with the non-modified liposome and Lipofectamine RNAiMax. This is likely because the modified polymer on the liposome surface suppressed the cytotoxicity of the cationic liposome. In addition, P(NIPAAm-co-DMAPAAm) modified liposome exhibited a slightly higher cell viability compared with P(NIPAAm-co-DMAAm) modified liposome. This result indicates that $\mathrm{P}$ (NIPAAm-co-DMAPAAm) modified liposome has a high transfection ability as well as low cytotoxicity. Therefore, P(NIPAAm-co-DMAPAAm) modified liposome is an appropriate temperature-responsive siRNA carrier. 


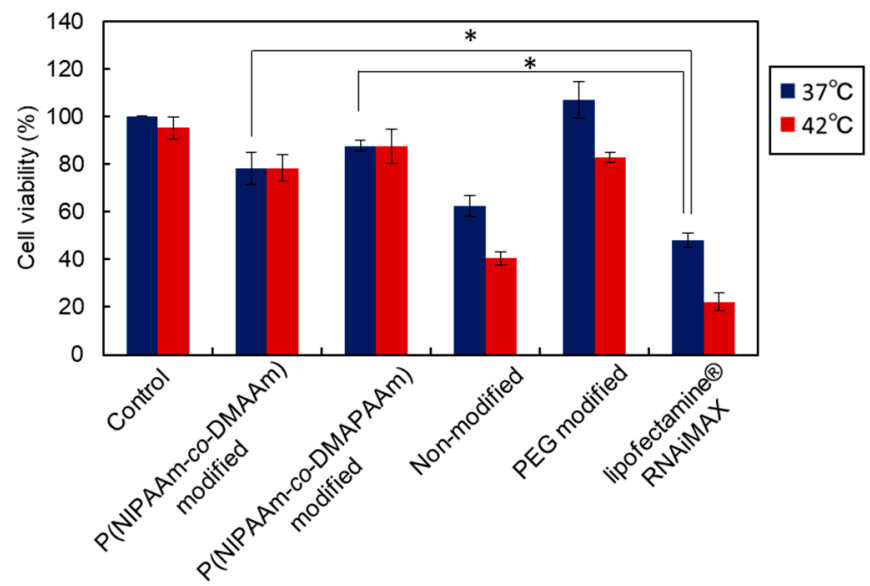

Figure 9. Cell viability of Luc-HeLa cells. siRNA was transfected for $4 \mathrm{~h}$ at $37^{\circ} \mathrm{C}$ or $42{ }^{\circ} \mathrm{C}$ followed by a $20 \mathrm{~h}$ incubation at $37^{\circ} \mathrm{C}$. Cell viability was evaluated by WST- 8 assay. The data are mean \pm standard deviation (SD) $\left(n=3\right.$ or $\left.4,{ }^{*} p<0.05\right)$.

Suppression of the VEGF expression of HeLa cells was carried out using P(NIPAAm-coDMAPAAm) modified liposomes (Figure 10). If VEGF expression of cancer cells in vivo is suppressed, angiogenesis and cancer cell growth can be prevented, leading to the possibility of using liposome-siRNA complexes as anti-cancer therapeutics. VEGF expression was estimated from the mRNA of VEGF. The VEGF expression was suppressed at $42{ }^{\circ} \mathrm{C}$ compared with the $37^{\circ} \mathrm{C}$ case. Previous reports have indicated that the VEGF expression of tumor cells was suppressed by heating at hyperthermia [44]. Therefore, the suppressed VEGF expression at $42{ }^{\circ} \mathrm{C}$ was reasonable. Using temperature-responsive liposomes as siRNA carriers for silencing VEGF expression effectively suppressed VEGF expression at $42{ }^{\circ} \mathrm{C}$, which is the same as was found when Lipofectamine RNAiMax was used as the siRNA carrier. This result indicated that temperature-responsive liposomes can modulate VEGF expression of cancer cells with temperature change, leading to the possibility of suppressing VEGF expression of cancer cells in vivo, thereby inhibiting cancer cell growth.

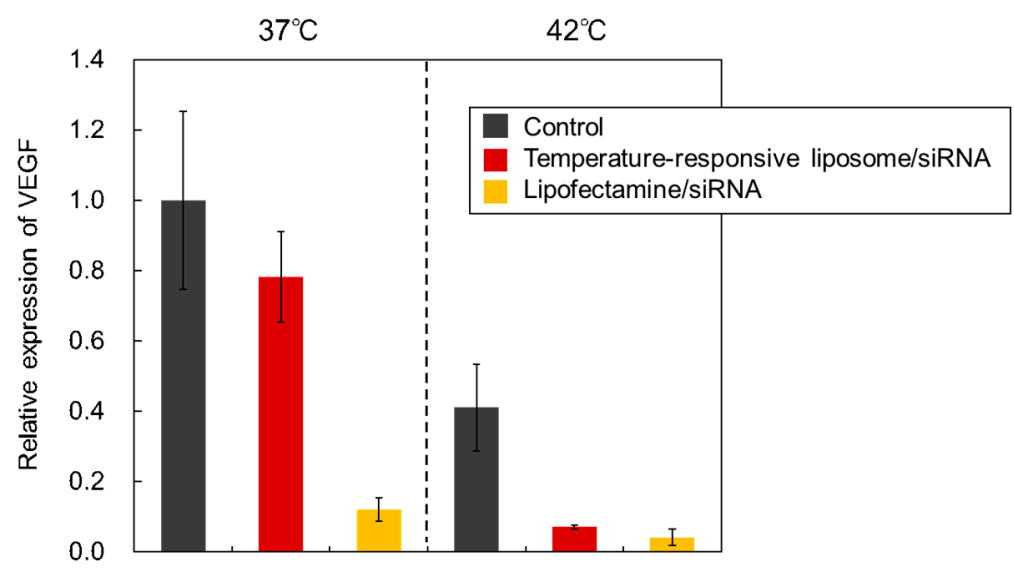

Figure 10. VEGF gene silencing using liposome-siRNA complexes in HeLa cells. Cells were treated with complexes for $4 \mathrm{~h}$ at $37^{\circ} \mathrm{C}$ or $42{ }^{\circ} \mathrm{C}$ followed by incubation for $44 \mathrm{~h}$ at $37^{\circ} \mathrm{C}$. VEGF mRNA levels were estimated by real time-PCR normalized to $\beta$-actin mRNA. The relative expression of VEGF was estimated by the VEGF expression level of HeLa cells at $37^{\circ} \mathrm{C}$ as a control. The error bars indicate the range of the relative expression of VEGF using real time PCR. The dotted line indicates the difference in incubation temperature.

These results indicated that P(NIPAAm-co-DMAPAAm) modified liposomes would be useful as siRNA carriers whose transfection can be modulated by external temperature. In addition, the 
temperature-responsive liposomes would be applicable not only in cell transfection in vitro, but also cancer therapy with hyperthermia.

\section{Materials and Methods}

\subsection{Materials}

$\mathrm{N}$-isopropylacrylamide (NIPAAm), N,N-dimethylacrylamide (DMAAm), and $\mathrm{N}, \mathrm{N}$ dimethylaminopropylacrylamide (DMAPAAm) were kindly provided by KJ Chemicals (Tokyo, Japan). NIPAAm was recrystallized from $n$-hexane. DMAAm and DMAPAAm were distilled. 2,2-azobisisobutyronitrile (AIBN), N,N-dimethylformamide (DMF), diethylether, acetone, bromothymol blue (BTB), L- $\alpha$-phosphatidyl ethanolamine, dioleoyl (DOPE), and chloroform were obtained from Wako Pure Chemical Industries, Ltd. (Osaka, Japan). Methanol, 3-mercaptopropionic acid (MPA) and $N, N^{\prime}$-dicyclohexylcarbodiimide (DCC) were obtained from Kanto Chemical (Tokyo, Japan). Chloroform-d $\left(\mathrm{CDCl}_{3}\right)$ was obtained from Tokyo Chemical Industries (Tokyo, Japan). 1,2-dioleoyl-3-trimethylammonium propane (chloride salt) (DOTAP) and 1,2-distearoyl-sn-glycero-3phosphoethanolamine- $N$-[amino(polyethylene-glycol)-2000] (ammonium salt) (DSPE-PEG2000) were obtained from Avanti Polar Lipids (Alabaster, AL, USA). Dulbecco's phosphate-buffered saline (D-PBS), Dulbecco's modified eagle medium (DMEM), Non-Essential Amino Acid Solution (NEAA), and minimum essential media (MEM) were purchased from Thermo Fisher Scientific (Waltham, MA, USA). BLOCK-iTTM Alexa Fluor ${ }^{\circledR}$ Red Fluorescent Control siRNA and lipofectamine RNAiMAX transfection reagent were also purchased from Thermo Fisher Scientific (Waltham, MA, USA). HeLa cells stably expressing a firefly luciferase (HeLa-Luc) were donated by Dr. Kenji Yamato (Tsukuba University, Tsukuba, Japan). HeLa cells were obtained from RIKEN cell bank (Tsukuba, Japan).

siRNAs were obtained from Sigma Aldrich (St Louis, MO, USA). The sequences were as follows: suppression of luciferase: sense: $5^{\prime}$-CCGUGGUGUUCGUGUCUAATT-3'; antisense: 5'-UUAGACACGAACACCACGGTT-3', suppression of VEGF: sense: 5'-GGAGUACCCUGAUGAG AUCTT-3'; antisense: 5'-GAUCUCAUCAGGGUACUCCTT-3'.

\subsection{Synthesis of Thermoresponsive Copolymers}

Two types of thermoresponsive copolymer-P(NIPAAm-co-DMAPAAm) and P(NIPAAm-coDMAAm) - were synthesized by radical polymerization using MPA as a chain transfer agent (Figure 1).

In the synthesis of P(NIPAAm-co-DMAAm), NIPAAm $(1.87 \mathrm{~g}, 16.5 \mathrm{mmol})$ and DMAAm $(1.13 \mathrm{~g}$, $7.2 \mathrm{mmol}$ ) (a NIPAAm to DMAAm ratio of 69.5:30.5), were dissolved in $6 \mathrm{~mL}$ of DMF in a flask. Then, MPA (31.8 mg, $0.30 \mathrm{mmol})$ and AIBN $(9.8 \mathrm{mg}, 0.06 \mathrm{mmol})$ were added to the solution. The reaction solution was deoxygenated by argon gas bubbling for $20 \mathrm{~min}$, and the flask was purged with nitrogen. The flask was then sealed, and the polymerization was allowed to proceed at $70{ }^{\circ} \mathrm{C}$ for $5 \mathrm{~h}$. After the polymerization, the copolymer was purified by reprecipitation using diethyl ether $(300 \mathrm{~mL})$ twice.

For P(NIPAAm-co-DMAPAAm) synthesis, NIPAAm (2.76 g, $24.36 \mathrm{mmol})$ and DMAPAAm (243.2 $\mathrm{mg}, 1.56 \mathrm{mmol}$ ) (a NIPAAm to DMAPAAm ratio of 94.0:6.0), were polymerized using the procedure described for P(NIPAAm-co-DMAAm).

\subsection{Characterization of Synthesized Polymers}

The phase transition behavior of the prepared polymers was observed by temperature dependent transmittance change of the polymer solution. Polymer solution was prepared by dissolving the polymer in PBS at a concentration of $5 \mathrm{mg} / \mathrm{mL}$. The transmittance of the polymer solution at $500 \mathrm{~nm}$ was measured using a UV-Vis spectrometer (V-630, JASCO, Tokyo, Japan) whilst heating the polymer solution at $0.1{ }^{\circ} \mathrm{C} / \mathrm{min}$. The lower critical solution temperature was defined as the temperature at which $50 \%$ transmittance was observed.

The molecular weight of the polymer was obtained by GPC (GPC-8020, Tosoh, Tokyo, Japan) using two serially connected TSK-Gel $\alpha$-M columns (Tosoh, Tokyo, Japan). The columns were calibrated 
using PEG standards. The mobile phase was DMF containing $10 \mathrm{mM}$ of $\mathrm{LiCl}$. The molecular weight of P(NIPAAm-co-DMAPAAm) was also determined by ${ }^{1} \mathrm{H}$ NMR. The sample solution was prepared by dissolving copolymers in $\mathrm{CDCl}_{3}$ at a concentration of $15 \mathrm{mg} / \mathrm{mL} .{ }^{1} \mathrm{H}$ NMR spectra were obtained using a nuclear magnetic resonance spectrometer (Varian INOVA 500, Varian, Palo Alto, CA, USA). The molecular weight of P(NIPAAm-co-DMAAm) was also obtained by titration molecular weight. The polymer $(25 \mathrm{mg}$ ) was dissolved in $2 \mathrm{~mL}$ of pure water. Titration of the terminal carboxyl group of the polymer was performed using $0.0025 \mathrm{~mol} / \mathrm{L} \mathrm{NaOH}$ solution.

\subsection{Conjugation of Thermoresponsive Polymer to Lipid}

To modify the liposomes with thermoresponsive polymer, the polymer was conjugated to the lipid component, L- $\alpha$-phosphatidylethanolamine, dioleoyl (DOPE). P(NIPAAm-co-DMAAm) (544 mg, $0.0403 \mathrm{mmol})$, DOPE $(30 \mathrm{mg}, 0.0403 \mathrm{mmol})$, NHS (20.8 mg, $0.1008 \mathrm{mmol})$, and DCC (11.6 mg, $0.101 \mathrm{mmol}$ ) were dissolved in $4 \mathrm{~mL}$ of chloroform in a flask. The flask was then purged with nitrogen and the reaction was allowed to proceed for $24 \mathrm{~h}$. After the reaction, the solvent was evaporated, and methanol was added. The solution was dialyzed using dialysis membrane of MWCO 3500 (Spectrum Laboratories, Rancho Dominguez, CA, U.S.A) for 2 days. After the dialysis, the solution was evaporated, and the sample was dried in vacuo. The obtained thermoresponsive polymer conjugated lipid was stored at $-30^{\circ} \mathrm{C}$. In the case of P(NIPAAm-co-DMAPAAm), P(NIPAAm-co-DMAPAAm) (443 mg, $0.0403 \mathrm{mmol}$ ) was used, and conjugation of the polymer to DOPE was carried out using the same reaction. The conjugation of the thermoresponsive polymers to DOPE was confirmed by ${ }^{1} \mathrm{H}$ $\mathrm{NMR}$ using $\mathrm{CDCl}_{3}$ as the solvent.

\subsection{Preparation of Thermoresponsive Polymer-Modified Liposomes}

Liposomes were prepared using DOTAP and DOPE because DOTAP has cationic properties and tends to form a complex with anionic siRNA, and DOPE has fusogenic properties for interaction with the cell membrane, leading to enhanced cellular uptake. Four types of liposome were prepared using the following procedure: DOTAP, DOPE, and P(NIPAAm-co-DMAAm)-DOPE were added to a flask at a molar ratio of 3:6.5:0.5, respectively, and dissolved in $3 \mathrm{~mL}$ of chloroform. The chloroform was then evaporated and a lipid film was formed on the internal surface of the flask. Pure water $(1 \mathrm{~mL})$ was added to the lipid film, which was then dispersed using a vortex mixer. The dispersed solution was added to a test tube and sonicated for $30 \mathrm{~min}$. The prepared liposome suspension was then extruded using an extruder with $100 \mathrm{~nm}$ pore diameter (Avanti Polar Lipids, Alabaster, AL, USA) to give P(NIPAAm-co-DMAAm) modified liposomes.

P(NIPAAm-co-DMAAm) modified liposomes and PEG modified liposomes were prepared in the same manner using P(NIPAAm-co-DMAPAAm)-DOPE or DSPE-PEG2000 in place of $\mathrm{P}$ (NIPAAm-co-DMAAm)-DOPE. To prepare non-modified liposomes, DOTAP and DOPE were used at the molar ratio of 3:7, respectively.

To prepare liposomes complexed with siRNA (lipoplexes), each liposome suspension (20 $\mathrm{mg}$ total lipid/mL water) and siRNA aqueous solution (200 mM stock concentration) were separately diluted with cell culture medium, mixed at a charge ratio (+/-) of 5:1 by vortex-mixing for $10 \mathrm{~s}$, and left for $30 \mathrm{~min}$ at room temperature. The liposome-siRNA complexes, with a final concentration of $50 \mathrm{nM}$ siRNA, were used immediately after the preparation. The theoretical charge ratio $(+/-)$ of cationic liposome to siRNA was calculated as the molar ratio of DOTAP to siRNA phosphate. Lipofectamine RNAiMAX (RNAiMAX) (Invitrogen, Corp., Carlsbad, CA, USA) was used for comparison, and transfection procedures were performed in accordance with the manufacturer's instructions.

\subsection{Liposome Characterization}

The size of the prepared liposomes was measured by dynamic light scattering. The liposome suspension was diluted 40 times with pure water or PBS, and the sample suspension was measured 
using a Zetasizer Nano-ZS (Malvern Instruments, Malvern, UK) to give the mean diameter of the liposomes.

The zeta potential of the liposomes was measured with an electrophoretic light scattering apparatus, ELSZK-2 KOP apparatus (Otuska Electronics, Osaka, Japan). The prepared liposomes were diluted 50 times with pure water. Zeta potential was then measured at $25^{\circ} \mathrm{C}$.

The stability of the prepared liposomes was evaluated by incubation of the liposomes with human serum. Commercially available human serum was diluted with $3 \mathrm{~mL}$ of pure water. The serum solution and the prepared liposome suspension was mixed at a ratio of 1:1. The absorbance of the liposome suspension was monitored at $450 \mathrm{~nm}$ for $24 \mathrm{~h}$.

The fixed aqueous layer thickness (FALT) of the prepared liposome was measured using previously reported methods [10]. The liposomes were prepared using a 9 weight percent sucrose solution. Sucrose solutions ( $9 \mathrm{wt} \%)$ with various $\mathrm{NaCl}$ concentrations $(0,5,10$, and $20 \mathrm{mmol} / \mathrm{L})$ were prepared. The prepared liposomes were diluted 50 times with sucrose solution containing various concentrations of $\mathrm{NaCl}$. The zeta potential of the liposomes was measured at 30,37, 42, and $50{ }^{\circ} \mathrm{C}$. The FALT was calculated using the following equation with Gouy-Chapman theory $[45,46]$. According to this theory, zeta potential $\zeta(L)$ was calculated from the electrostatic potential at the position of the slipping plane $L(\mathrm{~nm})$ and was expressed as the following equation.

$$
\ln \zeta(L)=\ln A-\kappa L
$$

where $A$ is a constant; $\kappa$ is the Debye-Hückel parameter-which is equal to $\sqrt{ } C / 0.3, C$ is the molar concentration of electrolyte- and $L$ is the slipping plane and FALT in nanometer.

\subsection{Cell Culture}

HeLa cells were cultured using MEM containing 10\% fetal bovine serum (FBS), 1\% MEM Non-Essential Amino Acids Solution (MEM NEAA), and $100 \mu \mathrm{g} / \mathrm{mL}$ penicillin streptomycin as the cell culture medium at $37^{\circ} \mathrm{C}$ in $5 \% \mathrm{CO}_{2}$. For passage culture, $0.05 \mathrm{wt} / \mathrm{v} \%$ trypsin-EDTA solution was used for harvesting cells, and the cell suspension was reseeded onto a $75 \mathrm{~cm}^{2}$ cell culture flask and incubated for 3 or 4 days.

Luciferase expressing HeLa cells (HeLa-Luc) were cultured using high glucose DMEM containing $10 \%$ fetal bovine serum (FBS), $1 \%$ MEM NEAA, and $100 \mu \mathrm{g} / \mathrm{mL} \mathrm{G-418} \mathrm{sulfate} \mathrm{as} \mathrm{the} \mathrm{cell} \mathrm{culture}$ medium at $37^{\circ} \mathrm{C}$ in $5 \% \mathrm{CO}_{2}$. For passage culture, 0.05 weight/volume $\%$ trypsin-EDTA solution was used for harvesting cells and the cell suspension was reseeded onto a $75 \mathrm{~cm}^{2}$ cell culture flask and incubated for 3 or 4 days.

\subsection{Gene Silencing of Luciferase Using siRNA Loaded Liposomes}

The gene silencing capabilities of the prepared siRNA loaded liposomes were investigated using luciferase expressing HeLa cells (HeLa-Luc). HeLa-Luc cells were seeded in a 6-well plate at a density of $7.5 \times 10^{4}$ cells / well. Cells were incubated at $37^{\circ} \mathrm{C}$ in $5 \% \mathrm{CO}_{2}$ for $24 \mathrm{~h}$, and cells adhered to the wells. Liposome-siRNA complex was prepared at an siRNA concentration of $25 \mathrm{nM}$. The liposome-siRNA complex solution $(1 \mathrm{~mL})$ was added to the HeLa-Luc incubated wells and a subsequent incubation was performed for $4 \mathrm{~h}$ at $37^{\circ} \mathrm{C}$ or $42{ }^{\circ} \mathrm{C}$. The cells were then rinsed with $1 \mathrm{mmol} / \mathrm{L}$ EDTA in PBS to remove liposomes adsorbed on the cell surfaces, and subsequently incubated at $37^{\circ} \mathrm{C}$ for $44 \mathrm{~h}$. After the incubation, cells were rinsed with PBS. Cells were then lysed to evaluate the luciferase activity. Cell lysis buffer (Promega, Madison, WI, USA) was used by diluting the reagent five times with PBS, and $250 \mu \mathrm{L}$ of diluted solution was added to the cells in the wells. The samples were then incubated at $37^{\circ} \mathrm{C}$ for $30 \mathrm{~min}$, after which the cell suspension was removed using a pipette and transferred to a $1 \mathrm{~mL}$ tube. The tube was incubated at $-80^{\circ} \mathrm{C}$ for $10 \mathrm{~min}$ to completely lyse the cells. The suspension was then centrifuged at $12,000 \mathrm{rpm}$ for $5 \mathrm{~min}$. The supernatant $(10 \mu \mathrm{L})$ was collected and $50 \mu \mathrm{L}$ of luciferase assay reagent (PicaGene ${ }^{\circledR}$ Luminescence Kit, Tokyo Ink, Tokyo, Japan), was added to the 
solution. The luminescence intensity was observed using a microplate reader (TECAN Infinite M1000, Zürich, Switzerland). In addition, the protein concentration of the $10 \mu \mathrm{L}$ of lysate was measured using a BCA protein assay kit (Thermo Fisher Scientific, Waltham, MA, USA). Luciferase activity in the cell lysates was measured as counts per second (cps), and the obtained value was divided per amount of protein (g) to cancel out the error due to differences in the amount of cells. Luciferase activity (\%) was obtained from the ratio of transfected cells to untreated cells.

\subsection{Suppression of VEGF Using siRNA Loaded Liposomes}

Suppression of VEGF expression was carried out using temperature responsive liposomes containing siRNA. Lipoplexs were prepared using VEGF suppressing siRNA [47,48]. The sequence is shown in the supporting information. HeLa cells were seeded in a 6-well plate at a density of $5.0 \times 10^{4}$ cells/well. Cells were incubated at $37^{\circ} \mathrm{C}$ in $5 \% \mathrm{CO}_{2}$ for $24 \mathrm{~h}$, and cells adhered to the well. Liposome-siRNA complex was prepared at an siRNA concentration of $25 \mathrm{nM}$. The Liposome-siRNA complex solution $(1 \mathrm{~mL})$ was added to the HeLa cells in the well, which were subsequently incubated for $4 \mathrm{~h}$ at $37^{\circ} \mathrm{C}$ or $42^{\circ} \mathrm{C}$. The cells were then rinsed with $1 \mathrm{mmol} / \mathrm{L}$ EDTA in PBS to remove liposomes adsorbed on the cell surface, and a subsequent incubation was carried out at $37^{\circ} \mathrm{C}$ for $44 \mathrm{~h}$. An RNA extraction reagent $(1 \mathrm{~mL})$ (ISOGEN, Nippon Gene, Tokyo, Japan) was added to the cells, which were then incubated for $5 \mathrm{~min}$ at room temperature. The cell lysate suspension was transferred to a $1.5 \mathrm{~mL}$ tube, $200 \mu \mathrm{L}$ of chloroform was added and the mixture was agitated with a vortex mixer. The suspension was centrifuged at $12,000 \mathrm{rpm}$ for $15 \mathrm{~min}$ at $4{ }^{\circ} \mathrm{C}$. The water layer $(400 \mu \mathrm{L})$ was combined with $320 \mu \mathrm{L}$ of isopropanol and mixed gently. The suspension was centrifuged at 13,800 rpm for $15 \mathrm{~min}$ at $4{ }^{\circ} \mathrm{C}$, and the supernatant was added to $1 \mathrm{~mL}$ of ethanol. The solvents were then allowed to evaporate on a clean bench. RNase-free water ( $44 \mu \mathrm{L})$, DNase I (10 units), and DNase I buffer $(5 \mu \mathrm{L})$ were added to the dried sample and incubated for $15 \mathrm{~min}$. Then, RNase-free water $(150 \mu \mathrm{L})$ and phenol-chloroform solution $(150 \mu \mathrm{L})$ were added and the mixture was agitated with a vortex mixer. The solution was centrifuged at $12,000 \mathrm{rpm}$ for $15 \mathrm{~min}$ at $4{ }^{\circ} \mathrm{C}$ and the water layer $(150 \mu \mathrm{L})$ was collected. Sodium acetate solution $(3 \mathrm{~mol} / \mathrm{L}, \mathrm{pH} 5.2,15 \mu \mathrm{L})$ and ethanol $(375 \mu \mathrm{L})$ were added to the collected aqueous layer solution. The solution was then incubated at $-20^{\circ} \mathrm{C}$ overnight. The solution was centrifuged at $15,000 \mathrm{rpm}$ for $15 \mathrm{~min}$ at $4{ }^{\circ} \mathrm{C}$ and rinsed with $75 \%$ ethanol. The ethanol was removed by decanting, and the sample was dried on a clean bench for $1 \mathrm{~h}$. The sample was then dissolved in $30 \mu \mathrm{L}$ of RNase-free water, and the RNA concentration was measured. To adjust the RNA concentration to $0.05 \mu \mathrm{g} / \mu \mathrm{L}, 5.8 \mu \mathrm{L}$ of Master Mix (Thermo Fisher Scientific, Waltham, MA, USA) and RNase-free water were added to the RNA solution. cDNA was synthesized by reverse transcription with a thermal cycler (C1000 ${ }^{\mathrm{TM}}$ Thermal Cycler, Bio-Rad, Hercules, CA, USA) at $25^{\circ} \mathrm{C}$ for $10 \mathrm{~min}$, $37^{\circ} \mathrm{C}$ for $2 \mathrm{~h}$, and $85^{\circ} \mathrm{C}$ for $5 \mathrm{~min}$.

SYBR Mix (Thermo Fisher Scientific, Waltham, MA, USA) $(5 \mu \mathrm{L})$, forward primer $(0.1 \mu \mathrm{L})$, reverse primer $(0.1 \mu \mathrm{L})$, and RNase-free water $(4.3 \mu \mathrm{L})$ were then added to the $200 \mu \mathrm{L}$ tube. The synthesized cDNA $(5 \mu \mathrm{L})$ was added to the mixed solution. PCR analysis was performed using a PCR apparatus with CFX Manager ${ }^{\mathrm{TM}}$ Software (Bio-Rad, Hercules, CA, USA). $\beta$-actin was used for normalization. The $\triangle \triangle C t$ method was used for calculation. The PCR primer sequences used were as follows. VEGF forward primer: AGGAGGGCAGAATCATCACG; VEGF reverse primer: CAAGGCCCACAGGGATTTTCT; $\beta$-actin forward primer: GTGGGGCGCCCCAGGCACCAGGGC; $\beta$-actin reverse primer: CTCCTTAATGTCACGCACGATTTC.

\subsection{Determination of Cellular Uptake by Fluorescence Microscopy}

HeLa-Luc cells were seeded in a $35 \mathrm{~mm}$ glass bottom dish at a density of $5.0 \times 10^{4}$ cells/well. Cells were incubated at $37^{\circ} \mathrm{C}$ in $5 \% \mathrm{CO}_{2}$ for $24 \mathrm{~h}$, and cells adhered to the dish. Liposome-siRNA complex was prepared at an siRNA concentration of $30 \mathrm{nM}$ and a charge ratio (+/ -) of 5:1. Liposome and Alexa fluor 555 labeled siRNA were suspended in DMEM without FBS (Biosera, Boussens, France), and the suspension was incubated for $30 \mathrm{~min}$. The cell culture medium in the well was then removed 
using an aspirator and the prepared liposome-siRNA complex solutions were added to the cells. The samples were then incubated at $37^{\circ} \mathrm{C}$ and $42{ }^{\circ} \mathrm{C}$ for $4 \mathrm{~h}$. The cells were rinsed with PBS containing $1 \mathrm{mmol} / \mathrm{L}$ EDTA. DMEM containing FBS was added to the cells and observation was carried out using a fluorescence microscope (Biorevo BZ-9000, Keyence, Osaka, Japan). The images were prepared by merging the phase contrast cell images and fluorescent siRNA images.

\subsection{Cell Viability Assessment}

The cytotoxicity of the prepared liposome-siRNA complex was evaluated by WST-8 assay. A HeLa cell suspension $\left(5.0 \times 10^{4}\right.$ cells $\left./ \mathrm{mL}, 100 \mu \mathrm{L}\right)$ was seeded into a 96-well cell culture plate and incubated at $37^{\circ} \mathrm{C}$ for $24 \mathrm{~h}$. The liposome-siRNA complex was prepared at an siRNA concentration of $25 \mathrm{nM}$. The cell culture medium in the 96-well plate was then removed and the prepared siRNA-liposome complex solution was added to the cells in the 96-well plate. The incubation was performed at $37^{\circ} \mathrm{C}$ or $42^{\circ} \mathrm{C}$ for $4 \mathrm{~h}$. After the incubation, the cells were rinsed with PBS containing $1 \mathrm{mM}$ EDTA, $100 \mu \mathrm{L}$ of cell culture medium was added, and the cells were incubated at $37^{\circ} \mathrm{C}$ for $20 \mathrm{~h}$. After the incubation, $10 \mu \mathrm{L}$ of WST-8 reagent solution (Dojindo, Kumamoto, Japan) was added to the cells in the well, and further incubation was carried out at $37^{\circ} \mathrm{C}$ for $1 \mathrm{~h}$. The absorbance at $450 \mathrm{~nm}$ was then measured using a plate reader (TECAN Infinite M1000, Zürich, Switzerland).

\subsection{Statistical Analysis}

Student's t-test was used for the statistical analysis of the obtained results. $p<0.05$ was considered statistically significant.

\section{Conclusions}

Temperature-responsive liposomes were prepared by modifying liposomes with two types of thermoresponsive polymer-P(NIPAAm-co-DMAPAAm) or P(NIPAAm-co-DMAAm). siRNA transfection properties were investigated by comparing non-modified liposome, PEG modified liposome, and commercially available siRNA carrier. The phase transition behavior of P(NIPAAm-co- DMAPAAm) showed a sharp phase transition compared with that of P(NIPAAm-co-DMAAm) because P(NIPAAm-co-DMAPAAm) had a lower co-monomer content compared with P(NIPAAm-co-DMAAm). Additionally, P(NIPAAm-co-DMAPAAm) modified liposomes exhibited a large change in the thickness of the fixed aqueous monolayer between $37^{\circ} \mathrm{C}$ and $42{ }^{\circ} \mathrm{C}$, while that of P(NIPAAm-co-DMAAm) modified liposomes changed over a broad temperature range. The thermoresponsive polymer-modified liposomes exhibited high stability in serum solution at $37^{\circ} \mathrm{C}$, as did PEG modified liposomes, while the non-modified liposomes aggregated rapidly. The temperature-responsive liposomes exhibited cellular uptake at $42{ }^{\circ} \mathrm{C}$, but were not taken up into cells at $37^{\circ} \mathrm{C}$. This is thought to be because the thermoresponsive hydrophilic/hydrophobic change of the liposome surface induced temperature responsive cellular uptake. Additionally, siRNA transfection of cells for prevention of luciferase activity and VEGF expression could be modulated by external temperature change. P(NIPAAm-co-DMAPAAm) modified liposomes in particular exhibited effective siRNA transfection properties with low cytotoxicity compared with P(NIPAAm-co-DMAAm) modified liposomes. These results indicated that the prepared temperature-responsive liposomes would be an effective siRNA carrier, whose transfection properties could be modulated by temperature.

Author Contributions: H.K., K.N., Y.M., E.A., and M.H. conceived and designed the experiments. M.H. performed the experiments and analyzed the data. K.N. and M.H. wrote the manuscript.

Funding: This study was supported by the MEXT-Supported Program for the Strategic Research Foundation at Private Universities, S1411004.

Conflicts of Interest: The authors declare no conflict of interest. 


\section{Abbreviations}

$\begin{array}{ll}\text { AIBN } & \text { 2,2-Azobisisobutyronitrile } \\ \text { BTB } & \text { Bromothymol blue } \\ \text { DCC } & N, N^{\prime} \text {-Dicyclohexylcarbodiimide } \\ \text { DMAAm } & N, N \text {-Dimethylacrylamide } \\ \text { DMAPAAm } & N, N \text {-Dimethylaminopropyl acrylamide } \\ \text { DMEM } & \text { Dulbecco's modified eagle medium } \\ \text { DMF } & N, N \text {-dimethylformamide } \\ \text { DOTAP } & \text { 1,2-Dioleoyl-3-trimethylammonium propane } \\ \text { DOPE } & \text { L- } \alpha \text {-phosphatidyl ethanolamine, dioleoyl } \\ \text { SPE } & \text { L- } \alpha \text {-distearoyl-phosphatidylethanolamine } \\ \text { FALT } & \text { Fixed aqueous layer thickness } \\ \text { GPC } & \text { Gel permeation chromatography } \\ \text { LCST } & \text { Lower critical solution temperature } \\ \text { MEM } & \text { Minimum essential media } \\ \text { NEAA } & \text { Non-Essential Amino Acid Solution } \\ \text { NIPAAm } & N \text {-isopropylacrylamide } \\ \text { NMR } & \text { Nuclear magnetic resonance } \\ \text { PEG } & \text { Polyethylene glycol } \\ \text { siRNA } & \text { Small interfering RNA } \\ \text { VEGF } & \text { Vascular endothelial growth factor }\end{array}$

\section{References}

1. Fire, A.; Xu, S.; Montgomery, M.K.; Kostas, S.A.; Driver, S.E.; Mello, C.C. Potent and specific genetic interference by double-stranded RNA in Caenorhabditis elegans. Nature 1998, 391, 806-811. [CrossRef]

2. Tuschl, T.; Zamore, P.D.; Lehmann, R.; Bartel, D.P.; Sharp, P.A. Targeted mRNA degradation by double-stranded RNA in vitro. Genes Dev. 1999, 13, 3191-3197. [CrossRef] [PubMed]

3. Zamore, P.D.; Tuschl, T.; Sharp, P.A.; Bartel, D.P. RNAi: Double-stranded RNA directs the ATP-dependent cleavage of mRNA at 21 to 23 nucleotide intervals. Cell 2000, 101, 25-33. [CrossRef]

4. Reynolds, A.; Leake, D.; Boese, Q.; Scaringe, S.; Marshall, W.S.; Khvorova, A. Rational siRNA design for RNA interference. Nat. Biotechnol. 2004, 22, 326-330. [CrossRef]

5. Amoozgar, Z.; Yeo, Y. Recent advances in stealth coating of nanoparticle drug delivery systems. Wiley Interdiscip. Rev. Nanomed. Nanobiotechnol. 2012, 4, 219-233. [CrossRef] [PubMed]

6. Vllasaliu, D.; Fowler, R.; Stolnik, S. PEGylated nanomedicines: Recent progress and remaining concerns. Expert Opin. Drug Deliv. 2014, 11, 139-154. [CrossRef] [PubMed]

7. Bai, J.; Zhou, Z.; Tang, H.; Song, S.; Peng, J.; Xu, Y. Impact of PEGylation on biodistribution and tumor accumulation of Lipid-Mu peptide-DNA. J. Liposome Res. 2013, 23, 1-10. [CrossRef]

8. Kono, K.; Nakai, R.; Morimoto, K.; Takagishi, T. Temperature-dependent interaction of thermo-sensitive polymer-modified liposomes with CV1 cells. FEBS Lett. 1999, 456, 306-310. [CrossRef]

9. Kono, K.; Ozawa, T.; Yoshida, T.; Ozaki, F.; Ishizaka, Y.; Maruyama, K.; Kojima, C.; Harada, A.; Aoshima, S. Highly temperature-sensitive liposomes based on a thermosensitive block copolymer for tumor-specific chemotherapy. Biomaterials 2010, 31, 7096-7105. [CrossRef]

10. Wang, J.; Ayano, E.; Maitani, Y.; Kanazawa, H. Tunable Surface Properties of Temperature-Responsive Polymer-Modified Liposomes Induce Faster Cellular Uptake. ACS Omega 2017, 2, 316-325. [CrossRef]

11. Wang, J.; Ayano, E.; Maitani, Y.; Kanazawa, H. Enhanced cellular uptake and gene silencing activity of siRNA using temperature-responsive polymer-modified liposome. Int. J. Pharm. 2017, 523, 217-228. [CrossRef] [PubMed]

12. Cammas, S.; Suzuki, K.; Sone, C.; Sakurai, Y.; Kataoka, K.; Okano, T. Thermo-responsive polymer nanoparticles with a core-shell micelle structure as site-specific drug carriers. J. Control. Release 1997, 48, 157-164. [CrossRef]

13. Akimoto, J.; Nakayama, M.; Okano, T. Temperature-responsive polymeric micelles for optimizing drug targeting to solid tumors. J. Control. Release 2014, 193, 2-8. [CrossRef] 
14. Nakayama, M.; Akimoto, J.; Okano, T. Polymeric micelles with stimuli-triggering systems for advanced cancer drug targeting. J. Drug Target. 2014, 22, 584-599. [CrossRef] [PubMed]

15. Kanazawa, H.; Yamamoto, K.; Matsushima, Y.; Takai, N.; Kikuchi, A.; Sakurai, Y.; Okano, T. Temperature-Responsive Chromatography Using Poly(N-isopropylacrylamide)-Modified Silica. Anal. Chem. 1996, 68, 100-105. [CrossRef] [PubMed]

16. Kikuchi, A.; Okano, T. Temperature-responsive, polymer-modified surfaces for green chromatography. Macromol. Symp. 2004, 207, 217-228. [CrossRef]

17. Nagase, K.; Kobayashi, J.; Okano, T. Temperature-responsive intelligent interfaces for biomolecular separation and cell sheet engineering. J. R. Soc. Interface 2009, 6 (Suppl. 3), S293-S309. [CrossRef]

18. Kanazawa, H.; Okano, T. Temperature-responsive chromatography for the separation of biomolecules. J. Chromatogr. A 2011, 1218, 8738-8747. [CrossRef]

19. Nagase, K.; Okano, T. Thermoresponsive-polymer-based materials for temperature-modulated bioanalysis and bioseparations. J. Mater. Chem. B 2016, 4, 6381-6397. [CrossRef]

20. Mori, T.; Maeda, M. Temperature-Responsive Formation of Colloidal Nanoparticles from Poly(N-isopropylacrylamide) Grafted with Single-Stranded DNA. Langmuir 2003, 20, 313-319. [CrossRef]

21. Lai, J.J.; Hoffman, J.M.; Ebara, M.; Hoffman, A.S.; Estournès, C.; Wattiaux, A.; Stayton, P.S. Dual Magnetic-/Temperature-Responsive Nanoparticles for Microfluidic Separations and Assays. Langmuir 2007, 23, 7385-7391. [CrossRef] [PubMed]

22. Matsuura, M.; Ohshima, M.; Hiruta, Y.; Nishimura, T.; Nagase, K.; Kanazawa, H. LAT1-Targeting Thermoresponsive Fluorescent Polymer Probes for Cancer Cell Imaging. Int. J. Mol. Sci. 2018, 19, 1646. [CrossRef] [PubMed]

23. Yamada, N.; Okano, T.; Sakai, H.; Karikusa, F.; Sawasaki, Y.; Sakurai, Y. Thermo-responsive polymeric surfaces; control of attachment and detachment of cultured cells. Makromol. Chem. Rapid Commun. 1990, 11, 571-576. [CrossRef]

24. Akiyama, Y.; Kikuchi, A.; Yamato, M.; Okano, T. Ultrathin Poly(N-isopropylacrylamide) Grafted Layer on Polystyrene Surfaces for Cell Adhesion/Detachment Control. Langmuir 2004, 20, 5506-5511. [CrossRef]

25. Takahashi, H.; Nakayama, M.; Yamato, M.; Okano, T. Controlled Chain Length and Graft Density of Thermoresponsive Polymer Brushes for Optimizing Cell Sheet Harvest. Biomacromolecules 2010, 11, 1991-1999. [CrossRef] [PubMed]

26. Nagase, K.; Watanabe, M.; Kikuchi, A.; Yamato, M.; Okano, T. Thermo-Responsive Polymer Brushes as Intelligent Biointerfaces: Preparation via ATRP and Characterization. Macromol. Biosci. 2011, 11, 400-409. [CrossRef] [PubMed]

27. Nagase, K.; Yamato, M.; Kanazawa, H.; Okano, T. Poly(N-isopropylacrylamide)-based thermoresponsive surfaces provide new types of biomedical applications. Biomaterials 2018, 153, 27-48. [CrossRef]

28. Nagase, K.; Okano, T.; Kanazawa, H. Poly(N-isopropylacrylamide) based thermoresponsive polymer brushes for bioseparation, cellular tissue fabrication, and nano actuators. Nano-Struct. Nano-Objects 2018, 16, 9-23. [CrossRef]

29. Akimoto, A.; Niitsu, E.; Nagase, K.; Okano, T.; Kanazawa, H.; Yoshida, R. Mesenchylmal Stem Cell Culture on Poly( $\mathrm{N}$-isopropylacrylamide) Hydrogel with Repeated Thermo-Stimulation. Int. J. Mol. Sci. 2018, 19, 1253. [CrossRef]

30. Kobayashi, J.; Arisaka, Y.; Yui, N.; Akiyama, Y.; Yamato, M.; Okano, T. Effect of Temperature Changes on Serum Protein Adsorption on Thermoresponsive Cell-Culture Surfaces Monitored by A Quartz Crystal Microbalance with Dissipation. Int. J. Mol. Sci. 2018, 19, 1516. [CrossRef]

31. Heskins, M.; Guillet, J.E. Solution Properties of Poly(N-isopropylacrylamide). J. Macromol. Sci. A 1968, 2, 1441-1455. [CrossRef]

32. Gil, E.S.; Hudson, S.M. Stimuli-reponsive polymers and their bioconjugates. Prog. Polym. Sci. 2004, 29, 1173-1222. [CrossRef]

33. Hoffman, A.S.; Stayton, P.S. Conjugates of stimuli-responsive polymers and proteins. Prog. Polym. Sci. 2007, 32, 922-932. [CrossRef]

34. Feil, H.; Bae, Y.H.; Feijen, J.; Kim, S.W. Effect of comonomer hydrophilicity and ionization on the lower critical solution temperature of N-isopropylacrylamide copolymers. Macromolecules 1993, 26, 2496-2500. [CrossRef] 
35. Takei, Y.G.; Aoki, T.; Sanui, K.; Ogata, N.; Okano, T.; Sakurai, Y. Temperature-responsive bioconjugates. 2. Molecular design for temperature-modulated bioseparations. Bioconj. Chem. 1993, 4, 341-346. [CrossRef]

36. Okano, T.; Bae, Y.H.; Jacobs, H.; Kim, S.W. Thermally on-off switching polymers for drug permeation and release. J. Control. Release 1990, 11, 255-265. [CrossRef]

37. Akimoto, J.; Nakayama, M.; Sakai, K.; Okano, T. Molecular design of outermost surface functionalized thermoresponsive polymeric micelles with biodegradable cores. J. Polym. Sci. Part A Polym. Chem. 2008, 46, 7127-7137. [CrossRef]

38. Akimoto, J.; Nakayama, M.; Sakai, K.; Okano, T. Temperature-Induced Intracellular Uptake of Thermoresponsive Polymeric Micelles. Biomacromolecules 2009, 10, 1331-1336. [CrossRef] [PubMed]

39. Akimoto, J.; Nakayama, M.; Sakai, K.; Okano, T. Thermally Controlled Intracellular Uptake System of Polymeric Micelles Possessing Poly(N-isopropylacrylamide)-Based Outer Coronas. Mol. Pharm. 2010, 7 , 926-935. [CrossRef] [PubMed]

40. Hiruta, Y.; Shimamura, M.; Matsuura, M.; Maekawa, Y.; Funatsu, T.; Suzuki, Y.; Ayano, E.; Okano, T.; Kanazawa, H. Temperature-Responsive Fluorescence Polymer Probes with Accurate Thermally Controlled Cellular Uptakes. ACS Macro Lett. 2014, 3, 281-285. [CrossRef]

41. Hiruta, Y.; Nagumo, Y.; Suzuki, Y.; Funatsu, T.; Ishikawa, Y.; Kanazawa, H. The effects of anionic electrolytes and human serum albumin on the LCST of poly( $N$-isopropylacrylamide)-based temperature-responsive copolymers. Colloids Surf. B 2015, 132, 299-304. [CrossRef] [PubMed]

42. Kanazawa, H.; Kashiwase, Y.; Yamamoto, K.; Matsushima, Y.; Kikuchi, A.; Sakurai, Y.; Okano, T. TemperatureResponsive Liquid Chromatography. 2. Effects of Hydrophobic Groups in N-Isopropylacrylamide Copolymer-Modified Silica. Anal. Chem. 1997, 69, 823-830. [CrossRef] [PubMed]

43. Nagase, K.; Kumazaki, M.; Kanazawa, H.; Kobayashi, J.; Kikuchi, A.; Akiyama, Y.; Annaka, M.; Okano, T. Thermoresponsive Polymer Brush Surfaces with Hydrophobic Groups for All-Aqueous Chromatography. ACS Appl. Mater. Interfaces 2010, 2, 1247-1253. [CrossRef] [PubMed]

44. Sawaji, Y.; Sato, T.; Takeuchi, A.; Hirata, M.; Ito, A. Anti-angiogenic action of hyperthermia by suppressing gene expression and production of tumour-derived vascular endothelial growth factor in vivo and in vitro. Br. J. Cancer 2002, 86, 1597-1603. [CrossRef]

45. Verwey, E.J.W. Theory of the Stability of Lyophobic Colloids. J. Phys. Colloid Chem. 1947, 51, $631-636$. [CrossRef] [PubMed]

46. Marra, J.; Israelachvili, J. Direct measurements of forces between phosphatidylcholine and phosphatidylethanolamine bilayers in aqueous electrolyte solutions. Biochemistry 1985, 24, 4608-4618. [CrossRef]

47. Kim, S.H.; Jeong, J.H.; Lee, S.H.; Kim, S.W.; Park, T.G. Local and systemic delivery of VEGF siRNA using polyelectrolyte complex micelles for effective treatment of cancer. J. Control. Release 2008, 129, 107-116. [CrossRef]

48. Christie, R.J.; Matsumoto, Y.; Miyata, K.; Nomoto, T.; Fukushima, S.; Osada, K.; Halnaut, J.; Pittella, F.; Kim, H.J.; Nishiyama, N.; et al. Targeted Polymeric Micelles for siRNA Treatment of Experimental Cancer by Intravenous Injection. ACS Nano 2012, 6, 5174-5189. [CrossRef]

(C) 2019 by the authors. Licensee MDPI, Basel, Switzerland. This article is an open access article distributed under the terms and conditions of the Creative Commons Attribution (CC BY) license (http:/ / creativecommons.org/licenses/by/4.0/). 